\title{
Assessment of Agricultural and Mining Pollutions of Waterbodies within the Nakanbé Basin (Burkina Faso): The Case of the Goinré, Ziga and Bagré Reservoirs
}

\author{
Dibi Millogo', Moméiyi Michée Bazié2, Youssouf Koussoubé3, Prosper Nabsanna Zombré2, \\ Evariste Constant Dapola $\mathrm{Da}^{4}$
}

${ }^{1}$ General Direction of the Nakanbé Basin Agency, Ziniaré, Burkina Faso

${ }^{2}$ Laboratory of Soils Science and Environment, Unit of Training and Research on Life and Earth Sciences, University Ouaga I Professor Joseph Ki-Zerbo, Ouagadougou, Burkina Faso

${ }^{3}$ Laboratory of Georessources and Environment, Unit of Training and Research on Life and Earth Sciences, University Ouaga I Professor Joseph Ki-Zerbo, Ouagadougou, Burkina Faso

${ }^{4}$ Laboratory of Physical Geography and Populations Dynamics, University Ouaga I Professor Joseph Ki-Zerbo, Ouagadougou, Burkina Faso

Email: evaristeda@gmail.com

How to cite this paper: Millogo, D., Bazié, M.M., Koussoubé, Y., Zombré, P.N. and Da, E.C.D. (2018) Assessment of Agricultural and Mining Pollutions of Waterbodies within the Nakanbé Basin (Burkina Faso): The Case of the Goinré, Ziga and Bagré Reservoirs. Journal of Water Resource and Protection, 10, 41-58.

https://doi.org/10.4236/jwarp.2018.101003

Received: October 27, 2017

Accepted: January 26, 2018

Published: January 29, 2018

Copyright $(9) 2018$ by authors and Scientific Research Publishing Inc. This work is licensed under the Creative Commons Attribution International License (CC BY 4.0).

http://creativecommons.org/licenses/by/4.0/

\section{(c) (i) Open Access}

\begin{abstract}
Agriculture is harming its own future through soil degradation and pollution of the water that it generates. The different chemical analyses carried out on surface waters and the land surveys carried out in the Nakanbé basin have shown that agricultural practices contribute to water pollution. The monitoring of nitrate, ortho-phosphate and $\mathrm{BOD}_{5}$ levels in the dams of Goinré, Ziga and Bagré during the period from August to December revealed that agricultural practices lead to variation in these parameters. The average values for nitrates are $0.833 \mathrm{mg} / \mathrm{L}$ in the Goinré fresh waterbody, $1.372 \mathrm{mg} / \mathrm{L}$ in the Ziga reservoir, and $1.267 \mathrm{mg} / \mathrm{L}$ in the Bagré fresh waterbody. As for ortho phosphate, mean values are $0.357 \mathrm{mg} / \mathrm{L}$ in the Goinré reservoir, $0.157 \mathrm{mg} / \mathrm{L}$ in the Ziga reservoir and $0.123 \mathrm{mg} / \mathrm{L}$ in the Bagré reservoir. These average values are higher than the norms established by Nisbet and Vernaux (1970) for eutrophication. Nitrates and orthophosphate are the elements that contribute to the eutrophication of water surfaces in the Nakanbé basin, although this eutrophication is of low intensity. Of all pesticides encountered in our study sites, 45\% are registered by the Sahelian Pesticides Committee (CSP): $35 \%$ are nonaccredited and $20 \%$ are unknown in the global list authorized by the CSP in 2010.
\end{abstract}




\section{Keywords}

Chemical Analyses, Agricultural Practices, Waterbody Pollution, Nakanbé

Basin, Eutrophication, Mining Practices

\section{Introduction}

Subject to the climate variability, to population explosion and to the low soil fertility [1] [2] [3], Burkina Faso agriculture is less productive. This agriculture is dominated by small family farms of 3 to 6 ha on average and by the use of rudimentary agricultural tools [4]. To meet the needs of this growing population, strong pressure is exerted on agricultural soils in order to obtain greater crop productions. This strong pressure on natural resources, due to the intensification of agriculture, always leads to a decreased level of soil fertility [4]. Through the clearing, excessive use of mineral fertilizers and the use of various types of plant protection products (pesticides), farmers intensively exploit their fields to the detriment of fallow. Agricultural intensification in Burkina Faso is concentrated mainly in the watersheds of the rivers, particularly those in the Volta, which are the suitable places for its development.

The Nakanbé basin is part of the upper basin of the Volta international river basin. Nakanbé is characterized by a high density of population (103 inhabitants $\left./ \mathrm{km}^{2},[5]\right)$ and a strong pressure on croplands impoverished by decades of continuous exploitation and climate deterioration from 1970 to 2000.

There are about 889 reservoirs in the basin. Bagré, Kompienga, Ziga, Loumbila and the dam of Toecé (commonly referred to as the Kanazoé dam) are the common ones.

On the agricultural level, 47 irrigated perimeters are identified in the Nakanbé basin, but the land area is only 2620 ha, including 1000 ha for Bagré (a mixed-use hydro-irrigation and hydroelectric dam). The regulated inland valleys cover almost 2175 ha. The irrigable areas are low compared to the potentialities that offer the available potential. Everywhere else, dams are used for animal watering and agriculture. Among the largest are the Kompienga hydroelectric dam (2.05 billion $\mathrm{m}^{3}$ in storage capacity) and the Ziga dam (200 million $\left.\mathrm{m}^{3}\right)$ for drinking water supply the capital Ouagadougou. We should like to add that fishing is important in a few dams, particularly in Bagré and Kompienga.

On the industrial level, the large companies mainly located in Ouagadougou are: breweriy (BRAKINA), slaughtehouse (Abattoir Frigorifique de Ouagadougou) and the tannery Tan-Aliz. Other important factories are Hage Materiaux (metal sheets and bars), FASOPLAST (plastic materials manufacturing), CNEA (National Center for Agricultural Equipment) and Cement factories (Diamond Cement, CIM metal, CIMAT).

Mining practice is one of the main sources of surface water bodies pollution, soils and plant contamination [6] [7] [8]. It should be noted the existence in the 
Nakanbé basin of numerous local gold mining sites where gold is mined artisanally near Kaya, Bittou, Koumbri, Seguénéga, Malou, Tikaré, Ouargaye and Yako. Various outside firms from Ghana, South Africa, Canada have been making prospecting and interesting reserves have allowed industrial exploitation: Kalsaka Mining, True Gold at Namissiguima, Bissa Gold, and soon Zinigma Gold Mining (Tikaré), Tenko Gold, Tanlouka Gold mining, Bomboré Gold (Orezone). In short, it is known that the degradation of the quality of surface water and consequently the groundwater can have different origins. But in this article, we will look mainly at the case of farming activity (subsistence agriculture, irrigation in particular) and its consequences on the quality of surface water. Indeed, the Nakanbé basin is the place where human activities, mainly agricultural ones, pose a threat to the physicochemical quality of the waters [9]. This exploitation has serious consequences on soil and water resources due to poor agricultural practices. Soils that are overexploited without fertility maintenance actions degrade. Surface water is polluted by fertilizers and pesticide residues caused by runoff. All these aspects relate the negative impact that agricultural practices have on natural resources, particularly on water, and it is then necessary to dwell on them. In the other hand, the place of mining activities is showed here in the degradation of the quality of waterbodies and consequently on soils quality.

The hypothesis of this study is as follows: agricultural practices contribute to surface water pollution in addition to other pollution sources such as mining activities.

The main objective of this article is to demonstrate the level of pollution of three water bodies or reservoirs in the Nakanbé basin.

\section{Materials and Methods}

\subsection{Framework of the Study}

The study takes place in the Nakanbé national hydrographic watershed, which covers $60,337 \mathrm{~km}^{2}$ and totally or partially covers seven administrative regions of Burkina Faso (13 regions compose Burkina Faso), namely Central Region, Central Plateau, Central East Region, Central South, Central North, Central West and Northern regions (Figure 1).

Its surface of approximately $41,407 \mathrm{~km}^{2}$ is drained by the Nakanbé, Massili, Koulipélé, Dougoulamondi, Tcherbo and Nouhao streams. The Nakanbé basin has about 889 reservoirs. Three artificial water reservoirs were chosen for this study: Goinré, Ziga and Bagré (Table 1).

In terms of the typology of these reservoirs taking into account the capacity, the dam of Bagré is classified among the large dams with a height of $9 \mathrm{~m}$, whereas that of Goinré is $4 \mathrm{~m}$. Other characters distinguish them. They are located in different climatic zones and the use differs from one reservoir to another.

- The reservoir Goinré

Located in the province of Yatenga, at $5 \mathrm{~km}$ in the north of Ouahigouya, the 


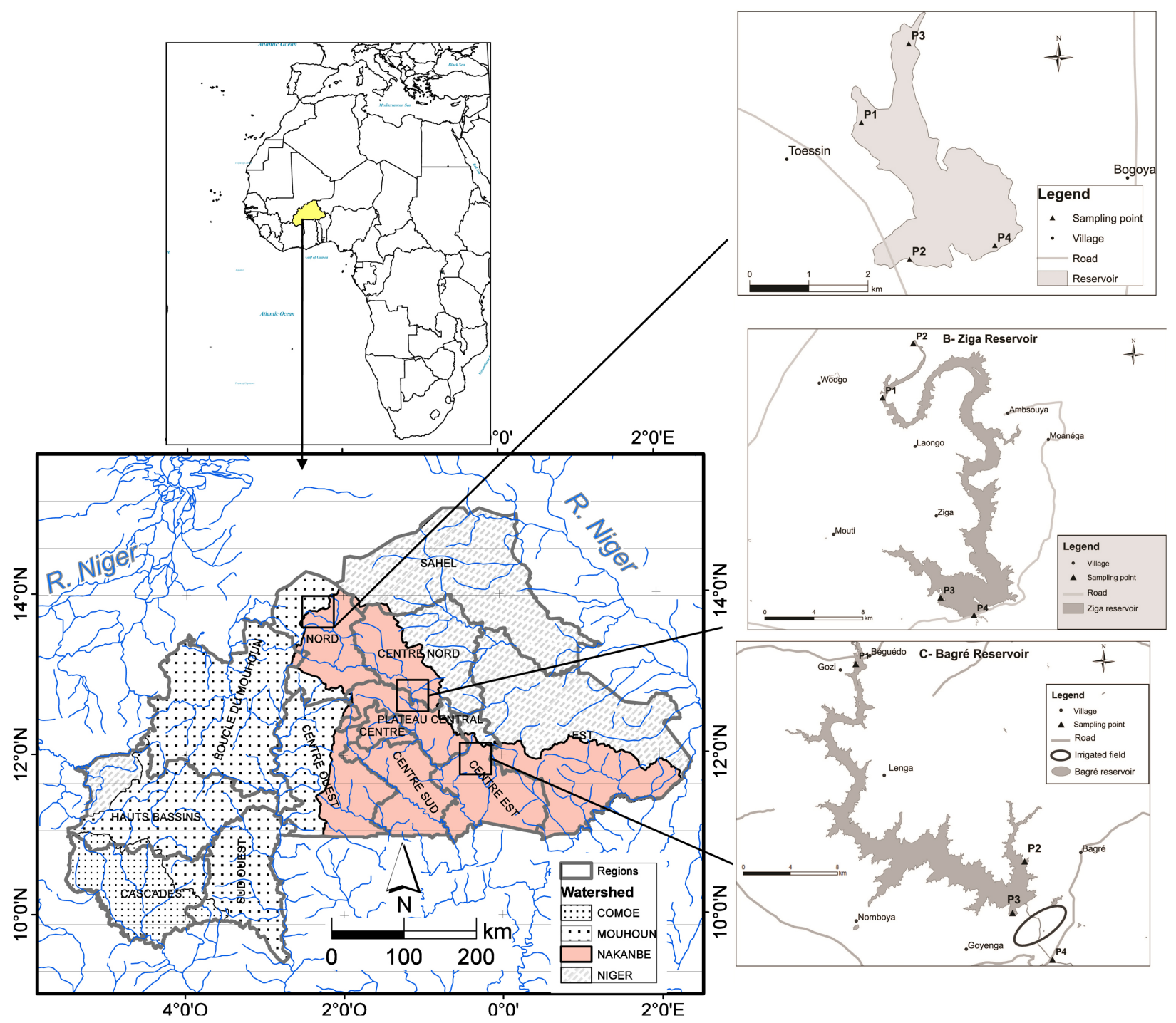

Figure 1. Localisation of study area and sampling points.

reservoir of Goinré has a capacity of about 1.9 million $\mathrm{m}^{3}$ (Figure 1(a)). Included between the meridians $2^{\circ} 27^{\prime}$ and $2^{\circ} 26^{\prime}$ west longitude and the parallel $13^{\circ} 37^{\prime}$ and $13^{\circ} 39^{\prime}$ north latitude; it is a hydro-agricultural reservoir. The climate is of the Sub-Sahelian type one with a rainfall between 600 and $750 \mathrm{~mm}$ in a normal year [10].

- The reservoir of Ziga

It is located in the Province of Oubritenga ("Central Plateau" region) and lies between meridians $1^{\circ} 11^{\prime}$ and $1^{\circ} 02^{\prime}$ west longitude and parallels $12^{\circ} 29^{\prime}$ and $12^{\circ} 46^{\prime}$ north latitude (Figure 1(b)). This reservoir is dedicated exclusively for drinking water supply of the capital Ouagadougou, with a capacity of 200 million $\mathrm{m}^{3}$. The climate is North-Sudanian one, characterized by a rainfall between 750 and 1000 $\mathrm{mm}$ and a dry season that lasts from 6 to 7 months.

- The reservoir of Bagré

With a capacity of 1700 million $\mathrm{m}^{3}$, the Bagré reservoir is located between 
Table 1. Some main lakes and reservoirs in the Nakanbé basin.

\begin{tabular}{ccc}
\hline $\begin{array}{c}\text { Reservoir (Dam) } \\
\text { or lake }\end{array}$ & $\begin{array}{c}\text { Capacity } \\
\text { in millions } \mathrm{m}^{3}\end{array}$ & Different uses \\
\hline Lake Bam & 41.2 & Irrigation; livestock \\
Lake Sian & 6 & Irrigation; livestock \\
Loumbila & 42.2 & Drinking water supply; Irrigation; livestock \\
Ouaga 2 + & 6.87 & Drinking water supply \\
Tougou & 5.8 & Irrigation; livestock \\
Titao & 4.27 & Irrigation; livestock \\
Goinré & 11.2 & Irrigation; livestock \\
Ouahigouya & 3.5 & Irrigation; AEP; livestock \\
Louda & 5.2 & Irrigation (riziculture) \\
Toécé & 90.5 & Irrigation; livestock \\
Ziga & 200 & Drinking water supply; livestock \\
Bagré & 1700 & Hydropower; irrigation; fishering; livestock \\
Kompienga & 2050 & Hydropower; irrigation; fichering; livestock \\
\hline Oumau Kanazoé) & & \\
\hline
\end{tabular}

meridians $0^{\circ} 14^{\prime}$ and $0^{\circ} 50^{\prime}$ west longitude and parallels $11^{\circ} 12^{\prime}$ and $11^{\circ} 53^{\prime}$ north latitude (Figure $1(\mathrm{c})$ ). It is a hydroelectric and agricultural dam and a great diversity of agricultural activities is carried out all around this reservoir. The climate of the Bagré dam is straddling the North Sudanian and South Sudanian zone. This South Sudanian zone is characterized by an inter-annual rainfall and is between 1000 and $1050 \mathrm{~mm}$, with a rainy season that lasts from 5 to 6 months.

\subsection{Sampling}

On each reservoir, four (4) sampling points were selected (Figure 1):

- The entry of water into the watercourse from upstream areas of high slopes, where we can find vegetable production in the dry season and cereal production in the rainy season;

- The entry of water into the watercourse coming from the surpluses water of the irrigated perimeters;

- At the spillway or the zone of convergence of the waters of the reservoir, two samples are taken on the left bank and on the right bank.

For each site, two (02) liters of water are collected at a depth of about $30 \mathrm{~cm}$ (to avoid the effect of the shore) and about 25 to 30 meters from the shore (to avoid the contamination of the shore). Water samples are collected in three (03) different periods (August, September and December 2011) and collected in sterile polyethylene bottles.

\subsection{Methodology of the Study}

A survey phase was carried out among the producers located around the three dams (Goinré 17 producers, Ziga 17 producers and Bagré 20 producers) in order 
to collect information on the various agricultural practices and inputs (fertilizers and pesticides) used.

The chemical analyzes were carried out at the water analysis laboratory of the National Office of Water and Sanitation and have concerned two types of parameters:

- The general physicochemical characteristics of the waters of Goinré, Ziga and Bagré by the monitoring of $\mathrm{pH}$; of the electrical conductivity and the turbidity,

- Some major and organic chemical characteristics by monitoring the nitrate content,

ortho-phosphate and the determination of BOD5 for the rate of biodegradable organic matter.

The statistical analyzes of the collected data were carried out using the XLSTAT-Pro software (version 7.5.2). The 5\% error threshold was used for comparisons of the averages with the Student Newman-Keuls test (SNK).

\section{Results}

\subsection{Field Surveys}

The results show that all the farmers around the three dams are male. The illiteracy rate is high with $76 \%$ in Goinré, $41 \%$ in Ziga and $65 \%$ in Bagré. In addition, there is a lack of training in agriculture. The history of the plots shows that $100 \%$ of the producers around the reservoir of Goinré, $75 \%$ around the reservoir of Ziga and $70 \%$ of the producers of Bagré work on parcels that they inherited from their parents. The rest of farmers work on plots that were fallowed.

Most of the rainfed crops are cereals (millet, maize, sorghum, rice). The market garden is practiced in the dry season and is mainly dominated by vegetables (tomatoes, cabbage, onions, cucumber). It takes place near water bodies, but the location of the plots depends on the previous rainfall. Some plots are on the bed of streams (Nakanbé) or bodies of water (Goinré). A high concentration of the practice of the market gardening is observed around the dams of Goinré and Bagré. Vegetable farming is prohibited in the vicinity of the Ziga reservoir in order to avoid pollution of the water; this surface water is mainly intended for drinking water supply, but there are vegetable producers who operate within the protection areas of the reservoir. In addition, gold-miners carry their ore on the banks upstream of the Ziga watercourse for the gravity treatment.

All producers continue to use daba (local hoe). To that we can add the plow with its different variants. Surveys revealed that $88.2 \%$ of producers use the cattletrucks at Goinré compared to $17.64 \%$ for the donkey-cart. In Ziga reservoir area, there is a high rate of utilization of the donkey-cart (70.56\%) compared to the cattle trucks (23.52\%). As for Bagré reservoir area, agricultural engines are more advanced in the rice perimeter. In addition to daba and plows, we notice the use of power tillers, harrows and tractors. Row planting is practiced by all surveyed producers. 
The Inputs Census revealed that a variety of pesticides are in use in the Nakanbé basin, but for mineral fertilizers only NPK (nitrogen + phosphorus + potassium) and urea have been found. Organic fertilizers are used with a strong application of manure (100\% of producers surveyed in Goinré and Ziga compared to $80 \%$ in Bagré). Despite the availability of plant biomass, composting is poorly practiced. In the three study sites, the application of mineral fertilizers is mainly carried out on vegetable and rice crops; Organic amendments are applied to cereals in the rainy season. The application rates of fertilizers are varied. In Bagré, in the rice perimeter, the recommendation for the application of mineral fertilizer is $200 \mathrm{~kg} / \mathrm{ha}$ of urea and $200 \mathrm{~kg} / \mathrm{ha}$ of NPK.

The pesticides encountered are mainly herbicides (25\% in Ziga and $64 \%$ in Bagré reservoirs) and insecticides (100\% in Goinré, $75 \%$ in Ziga and 36\% in Bagré reservoirs). These pesticides come from neighboring countries and are sold in market places or on roadsides. They are used by producers as needed and based on speculation about the effectiveness of the product. This involves varying doses and frequencies of application. Among all the pesticides encountered in our study sites, $45 \%$ are registered by the Sahelian Pesticides Committee (SPC), $35 \%$ are unregistered and $20 \%$ are unknown in the global list authorized by the SPC in 2010 .

\subsection{General Characteristics of the Surface Water of Goinré, Ziga, and Bagré}

The general physico-chemical characteristics (Table 2) reveal periods of high turbidity at the beginning of August and the average maximum values observed are 764 NTU at Goinré, 496 NTU at Ziga and 185 NTU at Bagré. These values will decrease over time in the reservoirs of Goinré and Ziga and will reach at the beginning of December minimum values of 160 NTU for the dam of Goinré and 216 NTU for Ziga. On the other hand for the dam of Bagré, a minimum value of 93 NTU is observed in early September, followed by an increase to 143 NTU during the rainy season.

The average $\mathrm{pH}$ during the study period have been 7.2 for Goinré and Ziga and 7.0 for Bagré.

The mean values of the electrical conductivity of the water are almost identical for the dam of Goinré $(83.4 \mu \mathrm{S} / \mathrm{cm})$ and Bagré $(84.8 \mu \mathrm{S} / \mathrm{cm})$; that of Ziga is 67.3 $\mu \mathrm{S} / \mathrm{cm}$.

These same ranges of values were found in the study on the quality of raw water in Burkina Faso in 2012 (respectively 81, 82 and $75 \mu \mathrm{S} / \mathrm{cm}$ ). This same study reveals differences in values depending on the season one is on the downstream part, on the banks, or on the upstream part of the reservoir.

In comparison with average rainfall values during the rainy season (Table 3 ), it is found that the $\mathrm{pH}$ values are all basic as in the measured surface waters. On the other hand, the electrical conductivity of the waters complies with international standards, but their average values are somewhat higher. The explanation 
Table 2. Mean values of some physico-chemical characteristics of the reservoirs.

\begin{tabular}{cccc}
\hline & $\mathrm{pH}$ & Turbidity in NTU & $\begin{array}{c}\text { Electrical } \\
\text { conductivity in } \mu \mathrm{S} / \mathrm{cm}\end{array}$ \\
\hline Goinré & $7.2 \pm 0.3$ & $373.3 \pm 291.8$ & $83.4 \pm 13.8$ \\
Ziga & $7.2 \pm 0.4$ & $312.8 \pm 324.4$ & $67.3 \pm 22.6$ \\
Bagré & $7.0 \pm 0.4$ & $140.1 \pm 142.8$ & $84.8 \pm 21.8$ \\
WHO standards [11] & $6.5-8$ & 5 & $50-150$ \\
\hline
\end{tabular}

Table 3. Monthly rainfall mean rates in Ouagadougou, Burkina Faso (University of Ouagadougou).

\begin{tabular}{cccc}
\hline Parameters & Units & Value & WHO standards [11] \\
\hline $\mathrm{T}$ & ${ }^{\circ} \mathrm{C}$ & 20 & $4-9$ \\
$\mathrm{pH}$ & & 7.2 & $50-150$ \\
$\mathrm{EC}$ & $\mu \mathrm{S} / \mathrm{cm}$ & 21 & - \\
$\mathrm{HCO}_{3}^{-}$ & $\mathrm{mg} / \mathrm{L}$ & 6.1 & - \\
$\mathrm{Cl}^{-}$ & $\mathrm{mg} / \mathrm{L}$ & 4.9 & 0.3 \\
$\mathrm{NO}_{2}^{-}$ & $\mathrm{mg} / \mathrm{L}$ & 0.002 & 50 \\
$\mathrm{NO}_{3}^{-}$ & $\mathrm{mg} / \mathrm{L}$ & 0.6 & 200 \\
$\mathrm{SO}_{4}^{-}$ & $\mathrm{mg} / \mathrm{L}$ & 2.4 & 200 \\
$\mathrm{Ca}^{++}$ & $\mathrm{mg} / \mathrm{L}$ & 3.2 & - \\
$\mathrm{Mg}^{++}$ & $\mathrm{mg} / \mathrm{L}$ & 0.49 & - \\
$\mathrm{Na}^{+}$ & $\mathrm{mg} / \mathrm{L}$ & 0.75 & - \\
$\mathrm{K}^{+}$ & $\mathrm{mg} / \mathrm{L}$ & 1 & \\
\hline
\end{tabular}

T: temperature; EC: electrical conductivity of water.

is to be found in the quality change of rainwater from runoff in contact with soil and agricultural waters. Rainfall is not turbid in August compared with the first very heavy rains and higher electrical conductivities (60 to $100 \mu \mathrm{S} / \mathrm{cm}$ ).

The Table 4 shows the concentrations of a previous of samplings and analyses of chemical, and heavy metals concentrations. The sampling was extended from the post-rainy season 2011 to mid-dry season (May-June 2012). For the various water reservoirs, 5 to 6 samples were taken depending on the size of the water body 1) at the spillway, 2) and 3) in the middle of the water reservoir 4) at the inlet of the reservoir, 5) and 6) on the right and left banks. In each case, sampling is done using a zodiac and taken at a minimum of $30 \mathrm{~cm}$ depth of water body according to the recommended protocol [12].

The surface water temperature is less than $29^{\circ} \mathrm{C}$ whatever the time of measurement in situ. They are found for the water bodies of Bagré and Gouinré. However, depending on the measuring equipment used, the $\mathrm{pH}$ meter or the conductivity meter, the levels of temperature is different. The thermometer seems to be less accurate than the conductivity meter. Thus if the temperature is 
Table 4. Physico-chemical, chemical, metal and cyanide contents in the reservoirs.

\begin{tabular}{|c|c|c|c|c|c|c|c|c|c|c|c|c|c|c|c|c|c|c|}
\hline & \multirow{2}{*}{$\begin{array}{c}\text { Reservoirs } \\
\text { Samples position }\end{array}$} & \multicolumn{6}{|c|}{ Ziga reservoir } & \multicolumn{6}{|c|}{ Bagré reservoir } & \multicolumn{5}{|c|}{ Gouinré reservoir } \\
\hline & & $\mathrm{a}$ & $\mathrm{b}$ & c & $\mathrm{D}$ & e & $\mathrm{f}$ & $\mathrm{a}$ & $\mathrm{b}$ & c & $\mathrm{d}$ & e & $\mathrm{f}$ & $\mathrm{A}$ & $\mathrm{b}$ & c & $\mathrm{d}$ & e \\
\hline \multicolumn{19}{|c|}{ WHO standards [11] } \\
\hline $\mathrm{T}^{\circ} \mathrm{C}$ & & 32.30 & 31.80 & 31.90 & 32.30 & 32.50 & 32.30 & 29.40 & 29.10 & 28.90 & 29.50 & 29.80 & 29.50 & 27.302 & 25.70 & 25.20 & 26.00 & 26.10 \\
\hline $\mathrm{pH}$ & & 7.64 & 7.73 & 7.79 & 7.75 & 7.71 & 7.67 & 7.36 & 7.75 & 7.58 & 7.57 & 7.81 & 7.58 & 7.53 & 7.65 & 7.62 & 7.86 & 7.93 \\
\hline $\mathrm{EC}\left(\right.$ at $\left.20^{\circ} \mathrm{C}\right)$ & & 82.00 & 82.30 & 82.10 & 82.30 & 82.50 & 82.20 & 72.30 & 72.20 & 75.10 & 76.70 & 77.40 & 78.50 & 82.208 & 81.70 & 82.10 & 81.00 & 80.80 \\
\hline Turbidity (NTU) & 5.00 & 48.05 & 49.01 & 64.55 & 87.711 & 115.40 & 99.781 & 105.10 & 099.25 & 119.30 & 140.10 & 0163.10 & 182.20 & 014.33 & 16.26 & 520.79 & 920.79 & 12.54 \\
\hline $\mathrm{TDS}(\mathrm{mg} / \mathrm{L})$ & 1000.00 & 82.00 & 82.00 & 82.00 & 82.00 & 83.00 & 82.00 & 72.00 & 72.00 & 75.00 & 77.00 & 77.00 & 79.00 & 82.008 & 82.00 & 82.00 & 81.00 & 81.00 \\
\hline $\operatorname{MES}(\mathrm{mg} / \mathrm{L})$ & 25 & 0.00 & 5.60 & 5.60 & 11.20 & 32.00 & 73.60 & 15.00 & 20.80 & 26.40 & 26.40 & 22.60 & 26.40 & 0.00 & 0.00 & 0.00 & 0.00 & 0.00 \\
\hline TA $\left({ }^{\circ} \mathrm{F}\right)$ & & 0.00 & 0.00 & 0.00 & 0.00 & 0.00 & 0.00 & 0.00 & 0.00 & 0.00 & 0.00 & 0.00 & 0.00 & 0.00 & 0.00 & 0.00 & 0.00 & 0.00 \\
\hline $\operatorname{TAC}\left({ }^{\circ} \mathrm{F}\right)$ & & 10.30 & 9.78 & 8.94 & 4.71 & 4.41 & 3.61 & 4.41 & 2.65 & 3.24 & 3.91 & 3.60 & 5.51 & 5.19 & 6.24 & 6.23 & 8.70 & 10.40 \\
\hline $\mathrm{TH}\left({ }^{\circ} \mathrm{F}\right)$ & 50.00 & 12.26 & 10.43 & 8.81 & 4.52 & 3.67 & 3.49 & 4.02 & 2.60 & 2.34 & 3.55 & 3.39 & 4.66 & 4.53 & 5.60 & 5.21 & 7.60 & 9.33 \\
\hline Dureté Calcique & & 3.11 & 3.28 & 3.60 & 2.69 & 2.19 & 2.16 & 1.59 & 1.69 & 1.43 & 1.71 & 1.84 & 2.17 & 3.18 & 3.04 & 2.69 & 2.34 & 2.42 \\
\hline $\mathrm{Ca}(\mathrm{mg} / \mathrm{L}$ & & 12.44 & 13.12 & 14.40 & 10.76 & 8.76 & 8.64 & 6.36 & 6.76 & 5.72 & 6.84 & 7.36 & 8.68 & 12.72 & 12.16 & 510.76 & 59.36 & 9.68 \\
\hline $\mathrm{Mg}(\mathrm{mg} / \mathrm{L})$ & & 22.14 & 17.30 & 12.61 & 4.43 & 3.58 & 3.22 & 5.88 & 2.20 & 2.20 & 4.45 & 3.75 & 6.03 & 3.27 & 6.20 & 6.10 & 12.73 & 16.72 \\
\hline $\mathrm{Na}(\mathrm{mg} / \mathrm{L})$ & 200.00 & 0.50 & 0.60 & 0.50 & 0.60 & 0.60 & 0.60 & 1.70 & 1.70 & 1.70 & 0.00 & 0.10 & 0.00 & 3.70 & 2.40 & 4.10 & 0.10 & 0.40 \\
\hline $\mathrm{K}(\mathrm{mg} / \mathrm{L})$ & & 2.40 & 2.40 & 2.60 & 2.40 & 2.20 & 2.30 & 0.40 & 0.40 & 0.40 & 1.50 & 1.50 & 1.50 & 2.00 & 1.90 & 2.00 & 3.80 & 4.50 \\
\hline FeTotal (mg/L) & 0.30 & 0.98 & 1.09 & 1.17 & 1.19 & 2.02 & 1.38 & 2.93 & 2.99 & 3.80 & 2.77 & 2.02 & 2.11 & 0.20 & 0.18 & 0.23 & 0.47 & 0.44 \\
\hline $\mathrm{NH}_{4}(\mathrm{mg} / \mathrm{L})$ & 1.50 & 0.21 & 0.15 & 0.16 & 0.22 & 0.58 & 0.44 & 0.73 & 0.77 & 0.84 & 0.73 & 0.62 & 0.76 & 0.11 & 0.16 & 0.13 & 0.14 & 0.19 \\
\hline $\mathrm{CO}_{3}(\mathrm{mg} / \mathrm{L})$ & & 0.00 & 0.00 & 0.00 & 0.00 & 0.00 & 0.00 & 0.00 & 0.00 & 0.00 & 0.00 & 0.00 & 0.00 & 0.00 & 0.00 & 0.00 & 0.00 & 0.00 \\
\hline $\mathrm{HCO}_{3}(\mathrm{mg} / \mathrm{L})$ & & 125.60 & 119.301 & 109.10 & 057.50 & 53.80 & 44.00 & 53.80 & 32.30 & 39.50 & 47.70 & 43.89 & 67.22 & 63.307 & 76.10 & 76.00 & 106.14 & 126.88 \\
\hline $\mathrm{Cl}(\mathrm{mg} / \mathrm{L})$ & 250.00 & 0.41 & 0.62 & 0.49 & 0.87 & 0.94 & 0.74 & 0.65 & 0.76 & 0.56 & 0.76 & 0.65 & 0.68 & 0.41 & 0.47 & 0.53 & 0.41 & 0.34 \\
\hline $\mathrm{SO}_{4}(\mathrm{mg} / \mathrm{L})$ & 250.00 & 6.00 & 6.00 & 6.00 & 2.00 & 2.00 & 2.00 & 2.00 & 2.00 & 2.00 & 4.00 & 4.00 & 2.00 & 2.00 & 2.00 & 2.00 & 2.00 & 2.00 \\
\hline $\mathrm{NO}_{2}(\mathrm{mg} / \mathrm{L})$ & 3.00 & 0.01 & 0.01 & 0.04 & 0.00 & 0.01 & 0.06 & 0.02 & 0.04 & 0.04 & 0.02 & 0.02 & 0.00 & 0.02 & 0.00 & 0.01 & 0.01 & 0.00 \\
\hline $\mathrm{NO}_{3}(\mathrm{mg} / \mathrm{L})$ & 50.00 & 16.72 & 5.72 & 6.60 & 1.32 & 0.44 & 1.32 & 3.52 & 7.04 & 5.72 & 3.08 & 0.44 & 0.44 & 0.44 & 0.44 & 0.44 & 0.44 & 0.44 \\
\hline $\mathrm{PO}_{4}(\mathrm{mg} / \mathrm{L})$ & & 0.19 & 0.48 & 0.48 & 3.68 & 0.56 & 0.50 & 0.41 & 0.37 & 0.18 & 0.82 & 0.63 & 0.20 & 0.39 & 0.29 & 0.22 & 0.44 & 0.26 \\
\hline $\mathrm{P}(\mathrm{mg} / \mathrm{L})$ & & 0.06 & 0.16 & 0.16 & 1.20 & 0.18 & 0.16 & 0.13 & 0.12 & 0.06 & 0.27 & 0.21 & 0.07 & 0.13 & 0.09 & 0.07 & 0.14 & 0.08 \\
\hline $\mathrm{F}(\mathrm{mg} / \mathrm{L})$ & 1.50 & 0.08 & 0.16 & 0.15 & 0.02 & 0.02 & 0.18 & 0.12 & 0.10 & 0.02 & 0.16 & 0.07 & 0.02 & 0.02 & 0.02 & 0.02 & 0.02 & 0.02 \\
\hline $\mathrm{CN}$ total $(\mathrm{mg} / \mathrm{L})$ & 0.07 & 0.18 & 0.12 & 0.11 & 0.12 & 0.05 & $<$ & $<$ & 0.15 & $<$ & 0.23 & 0.21 & 0.23 & 0.01 & 0.03 & 0.01 & $<0.005$ & 0.00 \\
\hline $\mathrm{Al}(\mathrm{mg} / \mathrm{L})$ & 0.20 & 1.28 & $<\mathrm{LD}$ & 1.51 & 0.10 & 0.92 & 1.77 & 0.01 & $<\mathrm{LD}$ & 0.47 & 0.82 & 0.11 & 0.57 & 0.64 & 0.71 & 0.19 & 1.50 & 0.02 \\
\hline As $(\mu \mathrm{g} / \mathrm{l})$ & 10.00 & 0.00 & 0.00 & 0.00 & 0.00 & 0.00 & 21.39 & 2.19 & 7.54 & 4.12 & 5.25 & 3.92 & 2.61 & 0.00 & 6.85 & 0.00 & 0.00 & 0.00 \\
\hline Cr total $(\mathrm{mg} / \mathrm{L})$ & 0.05 & $<\mathrm{LD}$ & 0.01 & $<\mathrm{LD}$ & $<\mathrm{LD}$ & 0.01 & $<\mathrm{LD}$ & $<\mathrm{LD}$ & $<\mathrm{LD}$ & $<\mathrm{LD}$ & $<\mathrm{LD}$ & $<\mathrm{LD}$ & $<\mathrm{LD}$ & $<\mathrm{LD}$ & 0.01 & $<\mathrm{LD}$ & $<\mathrm{LD}$ & 0.02 \\
\hline $\mathrm{Pb}(\mathrm{mg} / \mathrm{L})$ & 0.01 & 0.03 & 0.03 & 0.03 & 0.05 & 0.03 & 0.02 & 0.05 & 0.04 & 0.06 & 0.04 & 0.04 & 0.06 & 0.03 & $<\mathrm{LD}$ & $<\mathrm{LD}$ & $<\mathrm{LD}$ & $<\mathrm{LD}$ \\
\hline $\mathrm{Zn}(\mathrm{mg} / \mathrm{L})$ & 3.00 & 0.00 & 0.01 & 0.01 & 0.01 & 0.00 & 0.00 & 0.00 & 0.01 & 0.04 & 0.01 & 0.10 & 0.11 & 0.02 & 0.02 & 0.02 & 0.01 & 0.02 \\
\hline
\end{tabular}

a) at the spillway, b) and c) in the middle of the water reservoir d) at the inlet of the reservoir, e) and f) on the right and left banks; LD : limit of detection.

red quickly with the $\mathrm{pH}$ meter, the level of the temperature is similar to the value given by the conductivity meter. 
The $\mathrm{pH}$ is slightly basic for the three cases. However, depending on the position of the sample, a lower $\mathrm{pH}$ value is observed at the spillway (1) compared to the banks (5 and 6). This seems to be related to the clayey content of surface water with a high turbidity on the banks.

The electrical conductivity is of the order of 82 to Ziga and Gouinré, tendered to Bagré, it seems weaker (77). The spillway seems to present less conductive water than the banks or the upstream.

\subsection{Chemical and Organic Composition}

Chemical analyzes (Table 5) revealed a variation in the nitrate, ortho-phosphate and $\mathrm{BOD}_{5}$ levels over time in the three reservoirs. With relatively low values, analyzes of variance did not reveal any significant differences in the respective levels of nitrates, ortho-phosphates and $\mathrm{BOD}_{5}$ in the three reservoirs. Although variations were observed in each dam during the study period, the Student Newman-Keuls (SNK) test at the 5\% threshold did not reveal any significant difference between these values.

A decrease in nitrate levels in the Goinré (Figure 2(a)) and Ziga (Figure 2(b)) dams was observed during these three periods. Although the maximum values are low, ranging from $2 \mathrm{mg} / \mathrm{N}$ to Bagré at $7 \mathrm{mg} / \mathrm{N}$ in Ziga, analyzes show that growth is observed in periods of high rainfall, specifically August and September. In Bagré (Figure 2(c)), low values are observed in early August and September, followed by an increase in early December.

At Goinré (Figure 3(a)), high concentrations of ortho-phosphates are observed early in September. The maximum observed value, although low, is 1.26 $\mathrm{mg} / \mathrm{L}$. The contents of Ortho-phosphates are very weak at Ziga (Figure 3(b)) and at Bagré (Figure 3(c)); Ranging from 0.23 to $0.32 \mathrm{mg} / \mathrm{L}$, respectively, for their maximum values in these dams, these values increased from August to December at Bagré and decreased during the same period in Ziga.

Measurement of $\mathrm{BOD}_{5}$ or biochemical oxygen demand gives values similar to Goinré (Figure 4(a)) and Ziga (Figure 4(b)). The months of August and September are marked by a decrease in $\mathrm{BOD}_{5}$ in Goinré. The maximum values for these same periods are respectively 4.5 and $3.4 \mathrm{mg} \mathrm{O}_{2} / \mathrm{L}$. An increase in these

Table 5. Average nitrate, ortho-phosphate and BOD5 concentrations in surface water bodies.

\begin{tabular}{|c|c|c|c|}
\hline & $\begin{array}{l}\text { Nitrates } \\
(\mathrm{mg} / \mathrm{L})\end{array}$ & $\begin{array}{l}\text { Ortho-Phosphates } \\
\text { (mg/L) }\end{array}$ & $\begin{array}{c}\mathrm{BOD}_{5} \\
\left(\mathrm{mg} \text { of } \mathrm{O}_{2} / \mathrm{L}\right)\end{array}$ \\
\hline Goinré & 0.833 & 0.357 & 4.183 \\
\hline Ziga & 1.372 & 0.157 & 4.375 \\
\hline Bagré & 1.267 & 0.123 & 6.300 \\
\hline WHO standards [11] & 11.4 & - & - \\
\hline Eutrophication* & $\geq 0.3$ & $\geq 0.01$ & - \\
\hline
\end{tabular}

*Standards established by [14]. 


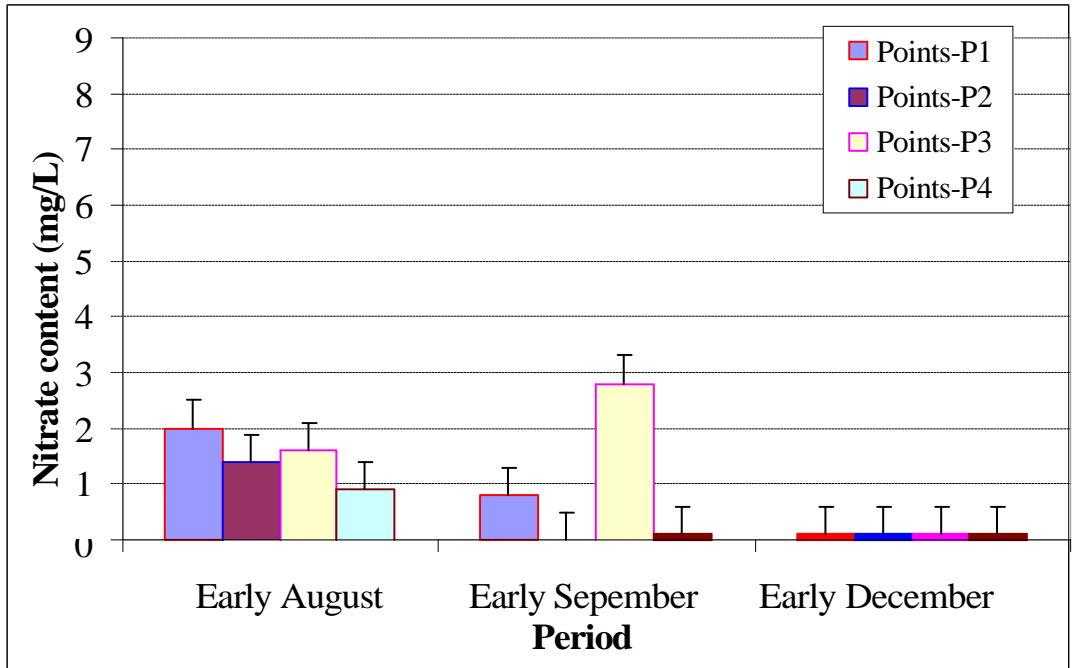

(a)

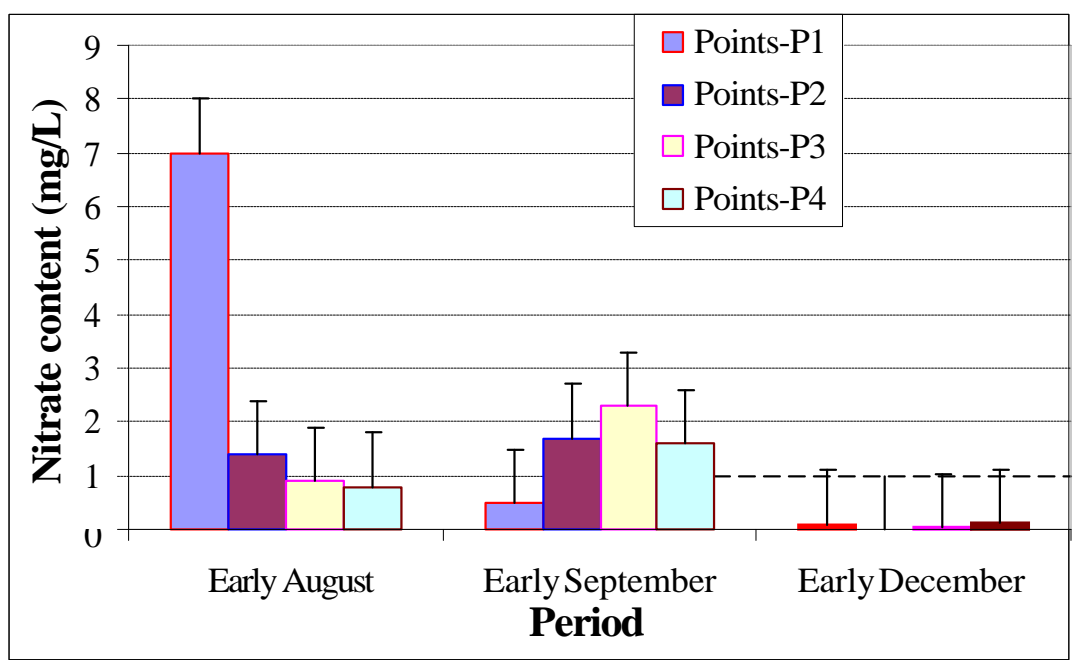

(b)

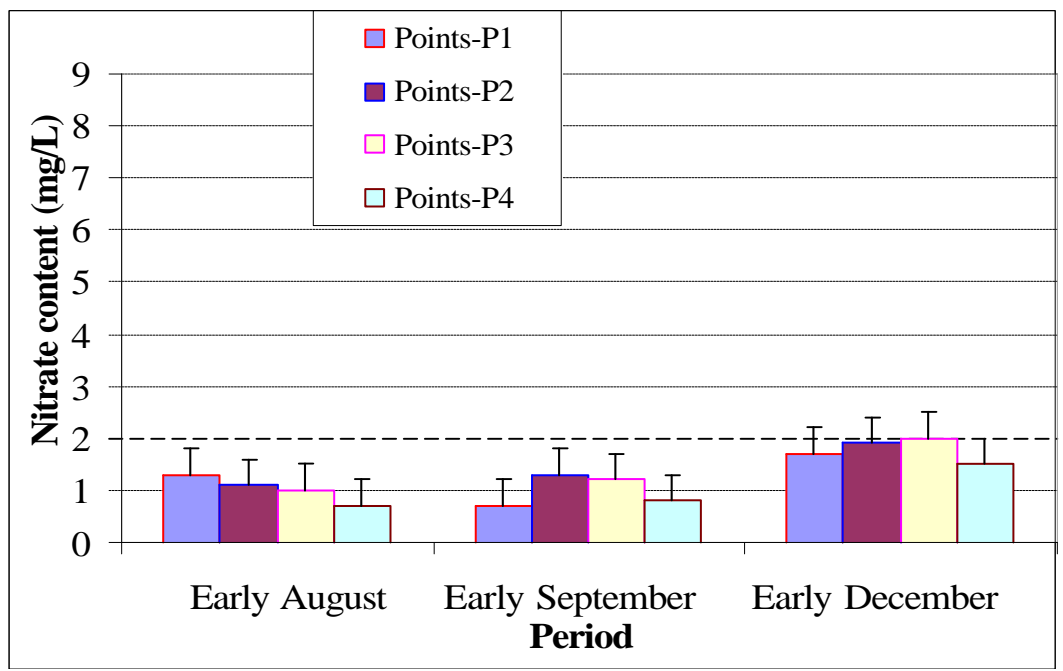

(c)

Figure 2. Nitrate content of Goinré (a); Ziga (b) and Bagré (c) reservoirs. 


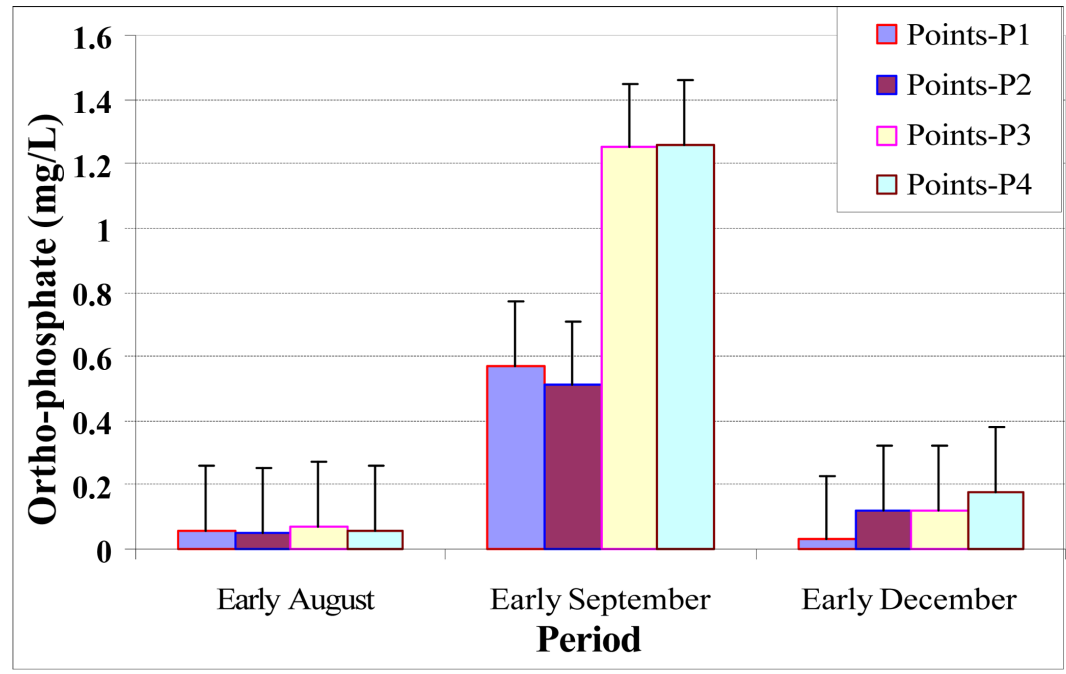

(a)

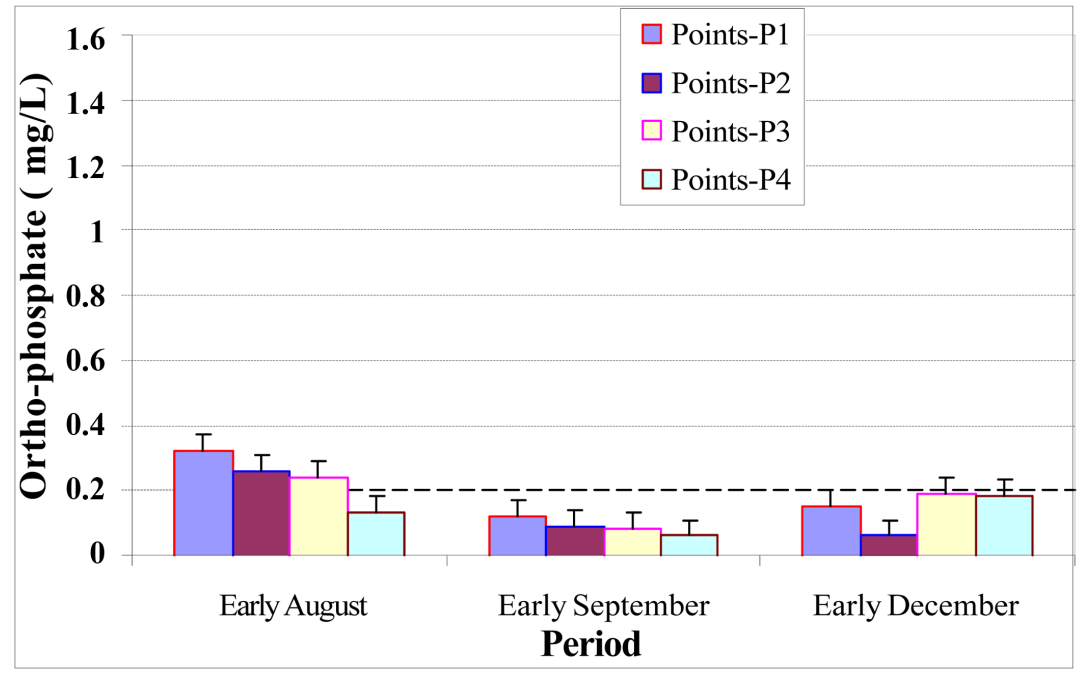

(b)

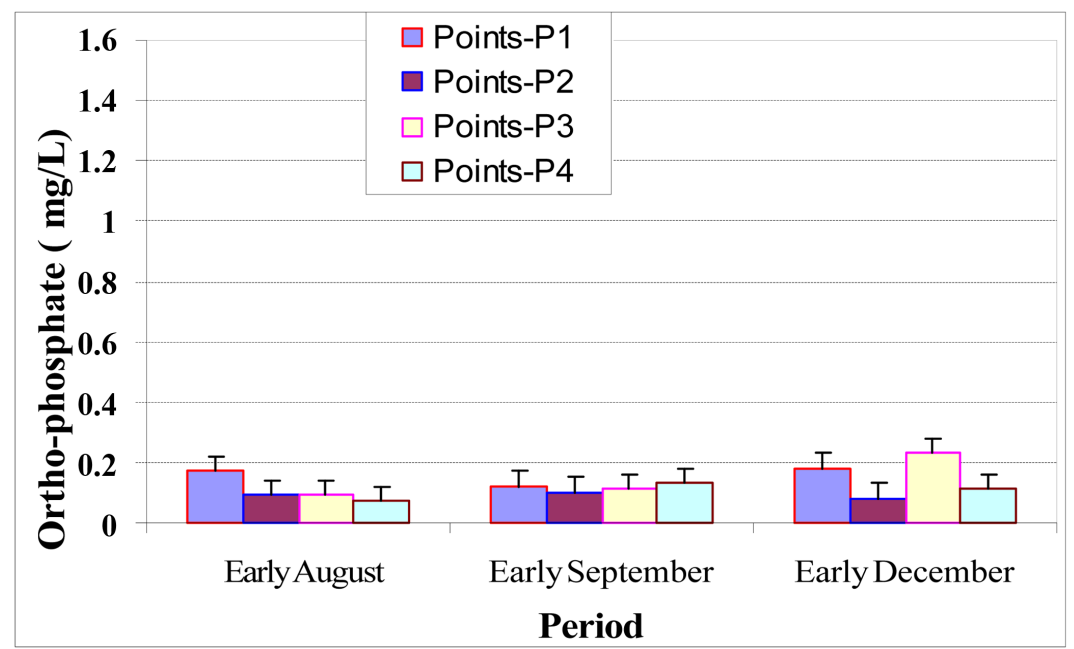

(c)

Figure 3. Ortho-Phosphate contents in Goinré (a); Ziga (b) and Bagré (c) reservoirs. 
values is observed in December reaching a maximum of $7.6 \mathrm{mg} \mathrm{O}_{2} / \mathrm{L}$. The opposite phenomenon is observed in Ziga. First, there is an increase in $\mathrm{BOD}_{5}$ values from August to September with maximum values of 6.2 and $6.8 \mathrm{mg} \mathrm{O}_{2} / \mathrm{L}$, respectively; and secondly, a drop in these values in early December. The minimum value is $1.7 \mathrm{mg} \mathrm{O}_{2} / \mathrm{L}$. In contrast to Bagré (Figure $4(\mathrm{c})$ ), the $\mathrm{BOD}_{5}$ contents decrease in all three periods. They ranged from 13.6 in August to $3.1 \mathrm{mg}$ $\mathrm{O}_{2} / \mathrm{L}$ in December.

\subsection{Cyanide and Metals Contents in Surface Water (Bagré, Ziga and Gouinré Reservoirs)}

Total cyanide is in excess at Ziga and Bagré reservoirs and the concentration range from 0.11 to $0.23 \mathrm{mg} / \mathrm{L}$. There is not a clear trend of high concentration depending on the sampling point; this result can show a high mobility of the pollutant.

About the heavy metals and metalloids levels; Arsenic (As), Lead (Pb), Aluminium (Al) and Total Iron (FeTotal) are most present at high levels in the larger reservoir of Ziga $(\mathrm{As}, \mathrm{Pb}, \mathrm{Al})$ and Bagré $(\mathrm{Pb})$. The gold ore is transported by the local miners to the large water bodies for washing or winnowing. The more difficult access to the banks, which are not frequented by populations, seem to be the zones where the concentration is more harmful.

The smaller reservoir of Gouinré does not indicate the presence of heavy metals at levels exceeding the WHO standards except in the border of the reservoir for FeTotal (Table 4).

\section{Discussion}

Agriculture is practiced by more than $80 \%$ of Burkina Faso population. This inheritance practice is transmitted from generation to generation. Producers continue to apply the practices they have received from their parents and this lead to a weak mechanization of agriculture. The lack of financial means is also a handicap for producers who continue to use traditional tools, using agricultural inputs in small proportions. The results of the survey show that the majority of producers continue to use daba (traditional hoe) for tillage. Added to this is the use of the plow with either the donkey-cart or the cattle track. This is the image of the whole country ([12]), asserts that the animal-drawn cultivation is highly appreciated by the farmers, as it saves time; and the use of daba is needed subsequently to improve plowing. That is why we have these results. For fertilizers, only NPK and urea were found as mineral fertilizers. Organic fertilizers are used with a strong application of manure (100\% of producers surveyed in Goinré and Ziga compared to $80 \%$ in Bagré). Despite the availability of plant biomass, composting is poorly practiced. In the three study sites, the application of mineral fertilizers is mainly carried out on vegetable and rice crops; Organic amendments are applied to cereals in the rainy season. The application rates of fertilizers are varied. 


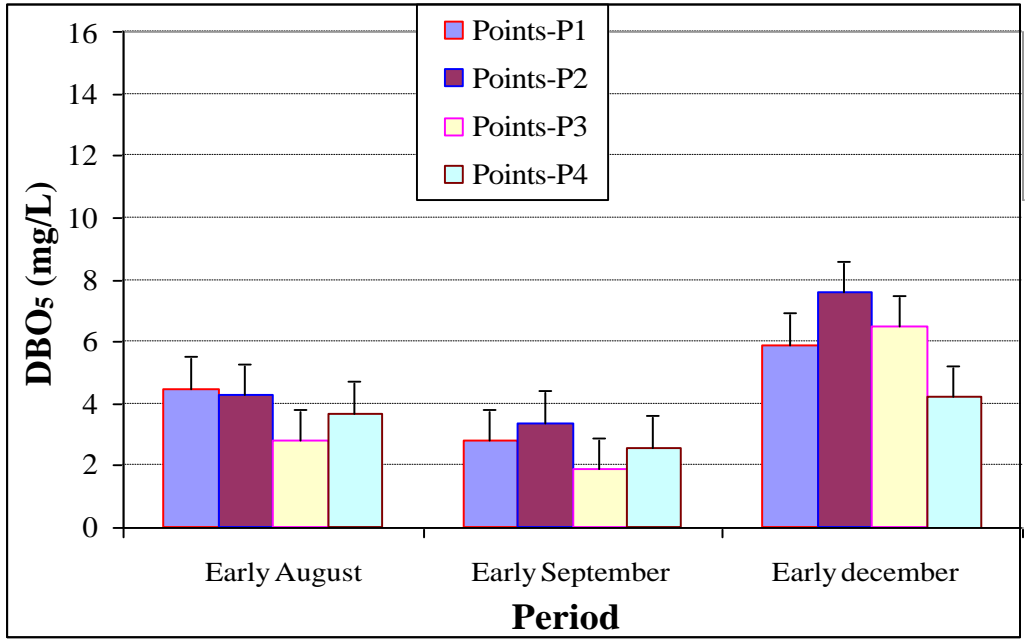

(a)

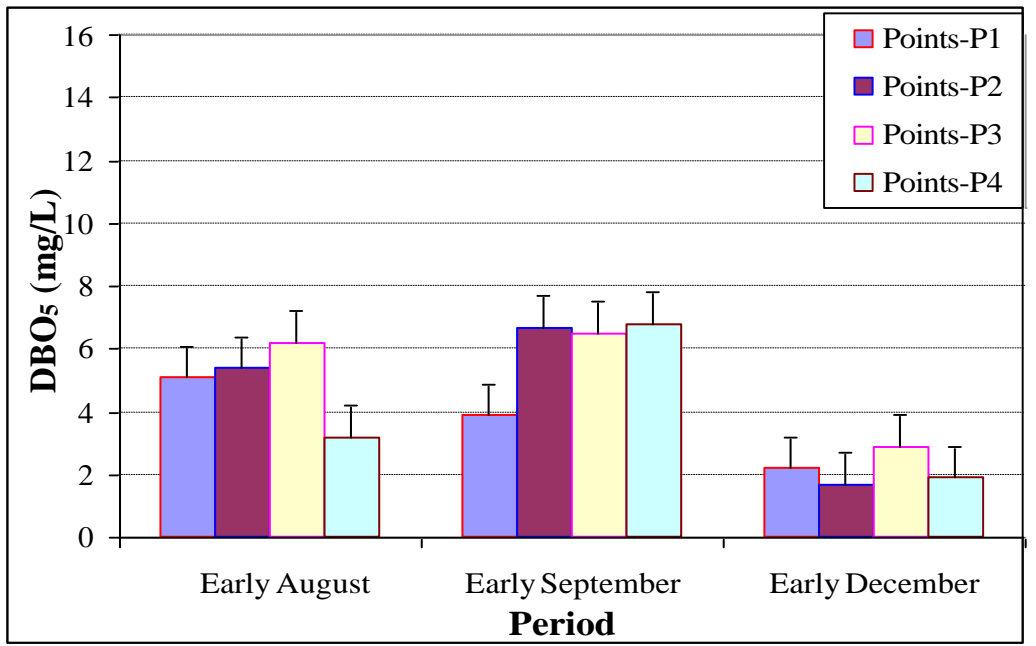

(b)

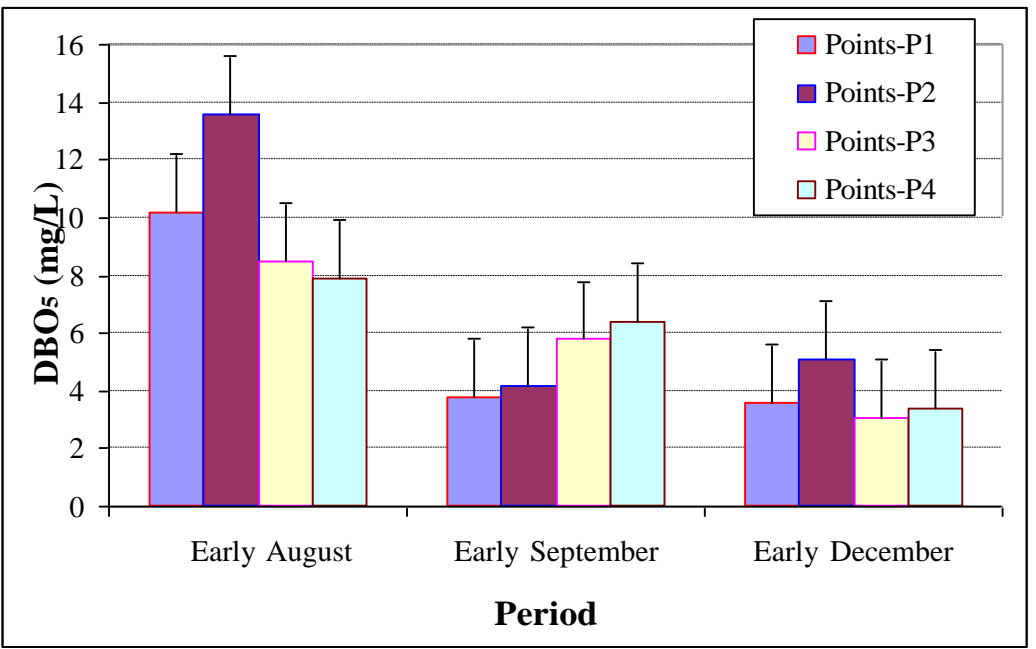

(c)

Figure 4. Change in $\mathrm{BOD}_{5}$ contents in the reservoirs of Goinré (a); Ziga (b) and Bagré (c). 
The results of the census of pesticides show that despite the controls on the entry of pesticides into the country, there are inadequacies, which shows that $35 \%$ of the pesticides encountered are not registered by the Sahelian Pesticides Committee (SPC) and that $20 \%$ of these pesticides are unknown. These results are consistent with those of [13].

The results on the general characteristics of the waters show that the average $\mathrm{pH}$ of the dams of Goinré, Ziga and Bagré respectively of 7.2; 7.1 and 7.0 comply with WHO standards $(6.5 \leq \mathrm{pH} \leq 8)$ for surface waters intended for drinking. These values that indicate neutrality reflect a natural $\mathrm{pH}$ where life develops in an optimal way.

As for turbidity, its values in the three reservoirs are above the WHO standards which is 5 NTU. Several phenomena can explain this high turbidity: first, the runoff of rainwater during the rainy season to the water reservoirs, which come from all parts carry several elements of various natures. Essentially made of fine or colored suspended materials, these elements give a turbid appearance to surface waters. Secondly, there is water erosion, causing land losses upstream. The absence of significant vegetation cover on the Nakanbé soils increases the rate of runoff. According to [14], the runoff coefficient in the Nakanbé can reach $57 \%$ with land losses of $5.5 \mathrm{~T} / \mathrm{ha} /$ year. The third phenomenon that explains this turbidity is the density of living beings present that can release enormous quantities of waste. This turbidity makes it more difficult to treat the waters of Ziga and Goinré for human consumption. With time, this can play either on the cost of treatment or on the quality of the water. Finally, it has negative repercussions on the consumer in terms of the quality and/or cost of water.

Electrical conductivity which is a numerical expression of the ability of a solution to conduct electric current reveals the rate of mineralization of water. The levels of the electrical conductivities have no significant difference in the Student Newman-Keuls (SNK) test and comply with the WHO 2004 standard. These conductivity values indicate that the waters of the three dams are very little mineralized, although electrical conductivity of the waters of Bagré and Goinre dams, are above that of the dam of Ziga. [15], confirm this weak mineralization of these waters by their work and place them in class 3 (out of 8).

The chemical parameters (nitrates, ortho-phosphates) and organic parameters (DBO5) of the three reservoirs have changed during the months of August to December. According to WHO drinking-water standards, nitrates are not responsible for pollution in the Goinré $(0.833 \mathrm{mg} / \mathrm{L})$, Ziga $(1.372 \mathrm{mg} / \mathrm{L})$ and Bagré $(1.267 \mathrm{mg} / \mathrm{L})$ dams. Nevertheless, in the month of August, the nitrate levels in Goinre and Ziga reservoirs are higher than above that of Bagré. This is due to the dumping of huge quantities of runoff through agricultural land upstream like it is encountered in other parts of the world [16]. The month of August is a period of heavy rain; then, the enormous quantities of rainwater that run off drain off the fertilizer residue from the fields to the water surfaces. For the Ziga and Goinré reservoirs, the decrease in nitrate levels from September to December in 
Ziga and Goinré is due to the end of the rainy season. On the other hand, the growth of the nitrate concentration observed in the Bagré dam from August to December with a maximum of $2 \mathrm{~m} / \mathrm{L}$ is due to the accumulation of water from upstream dams, of which reservoirs of Ziga and Goinré are included. In the water classification hierarchy according to [15], for the nitrates, the waters bodies of Ziga and Bagré are placed in the class 2 (out of 6) and that of Goinré is in the class 1. Nitrates participate in eutrophication of the waters bodies of these reservoirs because their average values are higher than the standards established by Nisbet and Vernaux for eutrophication. The presence of nitrates in drinking water causes discomfort in human beings, particularly the methaemoglobinaemia found in bottle-fed children [11].

Relatively low in the three reservoirs, the ortho-phosphate contents make it possible to estimate the degree of trophy of a body of water. The classification made by [15] places the waters of Bagré in class 3 (out of 6), Ziga waters in class 4 and that of Goinré in class 5. This indicates that ortho-phosphates contribute considerably to the eutrophication of the waters of these three dams. The waters of Bagré are moderately eutrophic, those of Ziga strongly eutrophic and those of Goinré polluted. Ortho-phosphates come mainly from the use of phosphate fertilizers in agriculture, industrial discharges and domestic discharges (human waste, detergents, washing products).

The nitrate levels obtained in the three dams are different from the results of [9]; As for ortho-phosphate, our results are in conformity with those of [9]. Depending on the standards on eutrophication, nitrates and orthophosphates contribute to the eutrophication of water in Goinré, Ziga and of Bagré reservoirs, although this eutrophication is low. These values are in line with those of [17], which places the reservoirs of Goinré, Ziga and Bagré in the zone of low eutrophication.

$\mathrm{BOD}_{5}$ measures the amount of dissolved oxygen consumed by aerobic organisms to ensure decomposition of the organic matter contained in the water examined in a period of 5 days. The higher the $\mathrm{BOD}_{5}$ is, the higher the amount of organic matter is present in the sample. For the authors [15], the waters of Bagré are in class 3 (out of 3) where the situation is abnormal, and the waters of Ziga and Goinré are in class 2 with a questionable situation. These high levels of organic matter have a variety of sources. They come on the one hand from the droppings of aquatic living beings, and on the other hand from runoff from all sides. The action of the germs will lead to the degradation of this organic matter. It is this activity of decomposition which ensures the self-purification of waters. $\mathrm{BOD}_{5}$ indicates that the organic matter is high in the three dams, but that of Bagré is higher. The phenomenon of self-purification of water contributes to a regulation of the rate of organic matter.

\section{Conclusions}

In the Nakanbé watershed, geological formations have high mineral and mining potentials (gold, silver, iron, bauxite, lead, cobalt, etc.) that allow the develop- 
ment of extractive industries, both artisanal and large-scale. The visible negative impacts of mining activities are generally remarkable through 1) deforestation and loss of biodiversity, 2) loss of arable land, 3) pollution of water resources and land by Heavy metals and 4) progressive intoxication of the food chain and humans through the bioaccumulation process [18]. Then, in this context the chemical analysis in some samples of the numerous reservoirs in the Nakanbé one is to understand the impact of the mining and agricultural practices in the soils. Agricultural practices are not without consequences for the surrounding reservoirs and rivers. In the Nakanbé basin, monitoring of nitrate levels, orthophosphate and $\mathrm{BOD}_{5}$ levels in the Goinré, Ziga and Bagré dams revealed that these parameters contribute to the eutrophication of these reservoirs. Although their values are relatively low, the quality of these waters must be controlled in order to avoid situations of irremediable pollution. The evolution of these different physicochemical characteristics of water resources has a direct consequence on the quality of water resources in this case, the reduction of its uses; which is a further challenge for the management of water resources due to the unavailability of the quality of water for certain uses. The causes of this decline in agricultural water quality are related to agricultural practices of resilience against climate change.

There is therefore a need to respect the precautionary principle regarding the innovations that we want to introduce for change and specifically with regard to water and to the environment.

By way of recommendations, we suggest that producers be better aware of good agricultural practices so that the environmental impacts of agriculture are known to all for good natural resource management. Strict control of the market for agricultural inputs (fertilizers and pesticides) and regular monitoring of water quality should be recommended in order to avoid disastrous situations.

\section{Acknowledgements}

This article will not be possible without the support of the ministry in charge of environment, the national service of soils studies of Burkina Faso. Many thanks to all. We would like to thanks the reviewers which contributions lead to increase the quality of this research.

\section{References}

[1] Aronson, J., Floret, C., Le Floc'h, E., Ovalle, C. and Pontanier, R. (1993) Restoration and Rehabilitation of Degraded Ecosystems in Arid and Semi-Arid Regions. A View from the South. Restoration Ecology, 1, 8-17. https://doi.org/10.1111/j.1526-100X.1993.tb00004.X

[2] Morin, J. (1993) Soil Crusting and Sealing in West Africa and Possible Approaches to Improved Management. Soil Tillage in Africa: Needs and Challenges, FAO Soils Bulletin, 69, 95-128.

[3] Ministère de l'Agriculture de l'Hydraulique et des Ressources Halieutiques - MAHRH (2004) Document de Stratégie de Développement Rural à l'Horizon 2010. Version définitive, Ouagadougou, 99. 
[4] Sedogo, M.P. (1993) Evolution des sols ferrugineux lessivés sous culture: influence des modes de gestion sur la fertilité. Thèse de Docteur Es-Sciences, Université Nationale de Côte d'Ivoire, Abidjan.

[5] Institut national de la statistique et de la démographie (Burkina Faso) (2016) Récensement général de la populations. Ouagadougou.

[6] Pravin, U.S., Kalpana, U.N. and Ram, S.L. (2011) Impact Assessment of Pollution in Some Lake Water Located at and around Thane City of Maharashtra, India: Physico-Chemical Properties and Toxic Effects of Heavy Metal Content. Interdisciplinary Environmental Review, 12, 215-230. https://doi.org/10.1504/IER.2011.041819

[7] Casado, M., Anawar, H.M., Garcia-Sanchez, A. and Santa Regina, I. (2008) Cadmium and Zinc in Polluted Mining Soils and Uptake by Plants (El Losar Mine, Spain). International Journal of Environment and Pollution, 33, 146-159. https://doi.org/10.1504/IJEP.2008.019389

[8] Banat, K.M., Howari, F.M. and Al-Shatnawi, S.Y. (2006) Stability and Environmental Geochemical Profile of Toxic Heavy Metals in Soils around a Crude Oil Refinery. International Journal of Environment and Pollution (IJEP), 28, No. 1/2. https://doi.org/10.1504/IJEP.2006.010882

[9] Somé, K., Dembélé, Y., Somé, L. and Millogo, J. (2008) Pollution des eaux dans le basin du Nakanbé : cas des réservoirs de Loumbila et de Mogtédo au Burkina Faso. Revue Sud Sciences et Technologies, ISSN 0796-5419, 16, 14-22.

[10] Guinko, S. (1984) Végétation de la Haute-Volta. Thèse de doctorat d'Etat, Université de Bordeaux II, Bordeaux, tomes 1 et 2, 394 p + annexes.

[11] Nisbet, M. and Verneaux, J. (1970) Composantes chimiques des eaux courantes. Discussion et proposition de classes en tant que bases d'interprétation des analyses chimiques. Annales de Liminologie, 6, 16-90. https://doi.org/10.1051/limn/1970015

[12] Toé, A.M. (2010) Étude pilote des intoxications dues aux pesticides agricoles au Burkina Faso. Rapport Final. Secrétariat de la Convention de Rotterdam, Rotterdam, $103 \mathrm{p}$.

[13] Nébié, O. (2005) Expérience de peuplement et stratégies de développement dans la vallée du Nakanbé Burkina Faso. Thèse de doctorat, Université de Neuchâtel (Suisse), Neuchâtel, $353 \mathrm{p}$.

[14] Ossana, N.A., Eissa, B.L. and Salibian, A. (2009) Cadmium Bioconcentration and Genotoxicity in the Common Carp (Cyprinus carpio). International Journal of Environment and Health, 3, 302-309. https://doi.org/10.1504/IJENVH.2009.028596

[15] Yacouba, H., Da, D.E.C., Yonkeu, S., Zombre, P.N. and Soule, M. (2002) Caractérisation du ruissellement et de l'érosion hydrique dans le bassin supérieur du $\mathrm{Na}$ kanbé (Burkina Faso). 5ème Conférence Inter-Régionale sur l'environnement et I'Eau - Envirowater, 5-8 November 2002, Ouagadougou, 318-325.

[16] Akkoyunlu, A. and Ileri, R. (2003) Evaluation of Eutrophication Process in Lake Sapanca (Sakarya, Turkey). International Journal of Environment and Pollution, 19, 576-602. https://doi.org/10.1504/IJEP.2003.004340

[17] Maiga, A.H., Konaté, Y., Denyigba, K., Karambiri, H. and Wethé, J. (2007) Eutrophisation et comblement des petites retenues d'eau en zone soudano-sahélienne du Burkina Faso. Actes des Journées Scientifiques Inter-Réseaux de l'Agence Universitaire de la Francophonie (JSIRAUF), Hanoi, 6-7 november 2007, 60 p.

[18] Secrétariat Permanent du Conseil National pour le développement durable (SP/CONEDD) (2010) Troisième rapport sur l'état de l'environnement au Burkina Faso. 263 p. 